
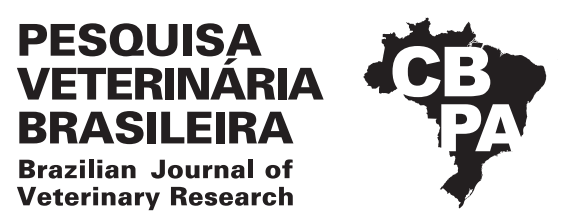

Pesq. Vet. Bras. 38(12):2183-2189, dezembro 2018 DOI: $10.1590 / 1678-5150-P V B-5300$

Original Article

ISSN 0100-736X (Print)

ISSN 1678-5150 (Online)

\title{
Expression patterns of mesenchymal stem cell-specific proteins in adipose tissue-derived cells: possible immunosuppressing agent in partial allograft for restoring the urinary bladder in rabbits ${ }^{1}$
}

\author{
Saulo T.L. Pinto Filho ${ }^{2 *}$, Micheli M. Pillat ${ }^{3}$, Matheus P. Rosa², Fabíola Dalmolin ${ }^{4}$, \\ Henning Ulrich ${ }^{3}$ and Ney L. Pippi ${ }^{2}$
}

\begin{abstract}
Pinto Filho S.T.L., Pillat M.M., Rosa M.P., Dalmolin F., Ulrich H. \& Pippi N.L. 2018. Expression patterns of mesenchymal stem cell-specific proteins in adipose tissuederived cells: possible immunosuppressing agent in partial allograft for restoring the urinary bladder in rabbits. Pesquisa Veterinária Brasileira 38(12):2183-2189. Hospital Veterinário Universitário, Universidade Federal de Santa Maria, Av. Roraima 1000, Prédio 97, Santa Maria, RS 97105-900, Brazil. E-mail: saulovet2011@hotmail.com

Adipose tissue-derived stem cells (ADSCs) are an attractive source of mesenchymal stem cells (MSCs) for use in tissue engineering and clinical applications. This paper focuses on the characterization of ADSCs used as immunosuppressive agent in rabbits undergoing partial allograft for urine bladder restorage. For this study highlighted the characterization of the ADSCs used as immunosuppressive agents in rabbits submitted to partial allograft for restoration of the urinary vesicle, using 25 animals, six months old, New Zealand. ADSCs at the third peal were characterized by the MSC-specific CD105, CD73 and CD90 expression and by the absence of the hematopoietic marker CD45, as revealed by flow cytometry analysis. Moreover, ADSCs were efficient in preventing allograft rejection from the urinary bladder, as judged by biochemical, clinical and ultrasonography analysis. Together, these results compose characterization of protein expression profiles and immunosuppressive functionality of ADSCs in rabbits, which had undergone partial allografts of the urinary bladder, foreseeing future applications in clinical practice.
\end{abstract}

INDEX TERMS: Expression patterns, mesenchymal stem cell, proteins, adipose tissue, derived cells, immunosuppressing agent, partial allograft, restoration, urinary bladder, rabbits, ADSC, cellular therapy, flow cytometry, clinics.

RESUMO.- [Padrão de expressão de proteínas específicas das células-tronco mesenquimais derivadas de tecido adiposo: possível agente imunossupressor em aloenxerto parcial para restauração de vesícula urinária de coelhos.] As células mesenquimais derivadas de tecido adiposo (ADSCs) são uma fonte atraente de células-tronco mesenquimais

\footnotetext{
${ }^{1}$ Received on May 9, 2018.

Accepted for publication on June 21, 2018.

${ }^{2}$ Hospital Veterinário Universitário, Departamento de Clínica de Pequenos Animais, Universidade Federal de Santa Maria (UFSM), Av. Roraima 1000, Prédio 97, Santa Maria, RS 97105-900, Brazil. *Corresponding author: saulovet2011@hotmail.com

${ }^{3}$ Departamento de Bioquímica, Instituto de Química, Universidade de São Paulo (USP), Av. Prof. Lineu Prestes 748, São Paulo, SP 05508-900, Brazil.

${ }^{4}$ Universidade Federal da Fronteira Sul, Campus Realeza, Rua Edmundo Gaievisk 1000, Zona Rural, Realeza, PR 85770-000, Brazil.
}

(MSCs) para uso na engenharia de tecidos e suas aplicações clínicas. Este trabalho destacou a caracterização das ADSCs utilizadas como agentes imunossupressores em coelhos submetidos a aloenxerto parcial para restauração da vesícula urinária, sendo utilizados 25 animais, de seis meses de idade, Nova Zelândia. As ADSCs, após o terceiro repique, foram caracterizadas pela expressão específica de MSC CD105, CD73 e CD90 e pela ausência do marcador hematopoiético CD45, tal como revelado por análise de citometria de fluxo. Além disso, os ADSCs foram eficientes na prevenção da rejeição de aloenxertos da vesícula urinária, conforme avaliado por análises clínica, bioquímica e ultrassonográfica. Juntos, esses resultados compõem a caracterização dos perfis de expressão proteica e a funcionalidade imunossupressora de ADSCs em coelhos, que sofreram aloenxertos parciais da bexiga, prevendo futuras aplicações na prática clínica. 
TERMOS DE INDEXAÇ̃̃O: Padrão de expressão, proteínas específicas, células-tronco mesenquimais, tecido adiposo, agente imunossupressor, aloenxerto parcial, restauração, vesícula urinária, coelhos, terapia celular, citometria de fluxo, clínica.

\section{INTRODUCTION}

The bladder is an organ of complex structure that can store large volumes, while simultaneously maintaining the pressure low between mictional periods. Injuries resulting from tumors, traumas, infections, inflammatory or neurological diseases affect their functional properties, leading to loss of continence and problems with urine storage, therefore damaging, sometimes in an irreversible way, the renal function. Thus, the great challenge, when one considers replacing the bladder, is to try to maintain or recreate its properties (Leite et al. 2014). Tissue engineering is a complex alternative to the functional reconstruction of the bladder. The culture of urothelial cells remains technically challenging, while muscle cells, of relatively simple culture, may not be easily obtained, mainly in cases requiring total or partial bladder replacement, such as cloacal or bladder exstrophy, and tumors. In this context, allotransplantation and stem cells may be excellent alternatives.

In this sense, Teixeira et al. (2007) studied urinary bladder allotransplantation in dogs by partial cystectomy preserving the trigone, using cyclosporine as an immunosuppressive agent. The authors concluded that urinary bladder allotransplant in dogs is viable, promoting repairing of urinary bladder capacity and other physiologic functions and resulting in partial regeneration of tissues 60 days after surgery.

At the same time, mesenchymal stem cells (MSCs) have been hailed as the great hope for the transplantation medicine, because they have been shown to be both multipotent and immunosuppressive (Technau et al. 2011, Larocca et al. 2013, Leite et al. 2014). The most common source of stem cells is the bone marrow. However, harvesting of bone marrow cells is a painful procedure with low yield of MSCs. These limitations have led to the search for alternative ways of obtaining stem cells, such as harvesting of undifferentiated mesenchymal cells from other tissues. In this context, adipose tissue-derived stem cells (ADSCs) are an attractive source of MSC for use in clinical applications. These cells have excellent plasticity and proliferative potential, undergo long-term proliferation, and are isolated in large quantities from adipose tissue using minimally invasive surgical procedures. In addition, they are able to grow by adherence to plastic or glass, making their isolation easy in the laboratory (Torres et al. 2007). Similar to other types of MSCs, it is well known that human ADSCs express the surface markers CD73, CD44, CD90 and CD105, but not the hematopoietic lineage markers CD11c, CD31, CD34, CD45, CD80 and CD86 (Dominici et al. 2006, Tárnok et al. 2010, Nery et al. 2013, Sousa et al. 2014).

Human ADSCs have been isolated from lipoaspirates and extensively characterized, however, ADSC from animal models, as such rabbits, are not well established and characterized. Rabbits have a large amount of adipose tissue and a used in basic science for different purposes for many years. Regarding tissue engineering approaches, rabbit animal models have been used for urethral, cartilage, and vocal fold reconstruction (Barretto et al. 2014).
This paper focuses on the characterization of expression profiles of clusters of differentiation (CDs) in rabbit ADSCs used as immunosuppressive agent in rabbits undergoing urinary bladder allografts. Moreover, we hypothesized that therapeutic application of rabbit ADSCs in partial allograft of urinary bladder could produce beneficial clinical results, since ADSCs could render the use of immunosuppressive drugs, as such cyclosporine, unnecessary.

\section{MATERIALS AND METHODS}

Ethics statement. Institutional review board approval of animal housing and experimental protocols was granted by the Committee of Ethics and Animal Use of the Federal University of Santa Maria, Brazil (protocol 066/2011).

Animals. Twenty-five healthy long-eared, six-months-old New Zealand White rabbits, weighing $3.73 \pm 0.88 \mathrm{~kg}$ were obtained from central animal facility of the Federal University of Santa Maria. Twenty-four females were used for development of urinary bladder transplantation, while a single male served as donor of ADSCs. The rabbits were housed in individual cages, inside a standard laboratory environment during two weeks of adaptive feeding before starting the surgeries. Animals were identified and separated in two groups (control group - CGcy and stem cell treatment group CGst), with 12 animals each one, according to the type of treatment. The groups were subdivided in two subdivisions with six animals each. All subgroups were evaluated following 15 and 30 days. After surgery transplantation surgery, the CGcy group was treated with cyclosporine $\left(5 \mathrm{mg} / \mathrm{kg}^{-1}\right)$, i.v., every 24 hours until the end of the studies. The CGst group received $1,6 \times 10^{5} \mathrm{ADSCs}(0.8 \mathrm{ml})$, processed and multiplied in our laboratory, used after the third passage. The cells were applied into the urinary wall, laterally to the suture between the graft and urinary bladder.

Clinical observations (feeding and urination behavior) were performed from the time of surgery to the end of the evaluation period for each group. Samples were collected for laboratory analysis, including blood and platelet count, BUN (Urea Nitrogen) and creatinine dosage, ALT (alanine aminotransferase), AST (aspartate aminotransferase), ALP (alkaline phosphatase) and urinalysis. Ultrasound evaluation was performed for bladder monitoring. Animals were submitted to euthanasia according to the time table of evaluation of each subgroup (15 days or 30 days).

Isolation and culture of rabbit ADSCs. For harvesting adipose tissue (AT) and processing of ADSCs, a male donor rabbit underwent the surgical procedure of lipectomy. Premedication consisted of intramuscular (i.m.) injection of a cocktail of ketamine hydrochloride $\left(20 \mathrm{mg} / \mathrm{kg}^{-1}\right)$, midazolam maleate $\left(2 \mathrm{mg} / \mathrm{kg}^{-1}\right)$ and morphine sulphate $\left(5 \mathrm{mg} / \mathrm{kg}^{-1}\right)$. Induction and maintenance of anaesthesia with isoflurane were done through the use of a mask. Subcutaneous AT in the interscapular adipose bag was removed under sterile conditions.

After washing with Hank's balanced salt solution (Sigma-Aldrich, St Louis, EUA) and removing AT membranes and blood vessels, ADSCs were isolated using the single collagenase digestion method. The AT were placed in $100 \mathrm{~mm}^{3}$ culture dishes, and digested for $30 \mathrm{~min}$ with $16 \mathrm{ml}$ of $0.1 \%$ type II collagenase (Sigma-Aldrich, St Louis, EUA) in a $37^{\circ} \mathrm{C}$ in water bath. The reaction was terminated by adding an equal volume of Dulbecco's Modified Eagle Medium (DMEM, Gibco, Grand Island/NY). Cells were filtered through a $200 \mu \mathrm{m}$-mesh nylon screen to remove undigested tissues. The lipid layer and supernatant were discarded after centrifugation. Cells were washed with PBS, and DMEM (containing 10\% foetal bovine serum (FBS, Gibco, Grand Island/NY) was added to obtain a single-cell suspension 
solution. Cells were then inoculated into $75 \mathrm{~cm}^{2}$ cell culture flasks and incubated in $37^{\circ} \mathrm{C}, 5 \% \mathrm{CO}_{2}$ cell culture incubator. Non-attached cells were discarded after 24 hours, and medium was replaced after 48 hours; after that, the culture medium was changed every other day (Zuk et al. 2002).

As a continuation of this study, a male rabbit was used to check the presence of the cells at the implantation site in the rabbits to search the Y chromosome, through SRY gene expression by PCR analysis.

Flow cytometry. Third peal cells in suspension were incubated for 20 min in PBS containing 3\% FCS for blocking of nonspecific sites. Subsequently, cells were incubated with anti-CD105 PerCPCy5.5 (1:5), anti-CD90 PE (1:5), and anti-CD45 FITC (1:20) or anti-CD105 PerCPCy5.5, anti-CD90 PE, and anti-CD73 FITC (1:10) antibodies at dilutions according to the manufacturer procedures (BD bioscience). Although there were commercially validated antibodies to rabbits, they were not found in the suppliers and therefore, those of humans. After 30 min of incubation with the antibodies at room temperature, cells were washed with PBS and resuspended in $400 \mathrm{ml}$ PBS for data acquisition with the BD FACS flow cytometer (Becton and Dickinson Biosciences). A minimum of 30.000 cells per sample were analysed and gated for forward scatter (FSC) versus side scatter (SSC) channel signals. Analyses were performed with the FlowjoV10 software. The negative control sample consisted of cells not exposed to antibody labelling. From this sample traced to the quadrants, events observed beyond the lower left quadrant (containing the negative sample) were considered positive (Pillat et al. 2009).

Bladder transplant procedure. Anaesthetized animals were operated in pairs, with simultaneous procedures at the same operating room and each female rabbit was donor and recipient of bladder. The urine was removed, and approximately $30 \%$ of the bladder was excised at the cranial portion, leaving repairs points at the remaining portion. After the end of implant suture and bladder repletion test, ADSCs were placed as explained above.

Immediately after surgery, animals were monitored until complete restoration of consciousness and then returned to their individual cages. Tramadol hydrochloride was administered $\left(6 \mathrm{mg} / \mathrm{kg}^{-1}\right)$, i.m., every eight hours for three days. Cleaning of the wound was carried out with $0.9 \% \mathrm{NaCl}$ solution once every two days. Skin sutures were removed seven days after surgery. During this time animals were clinically evaluated in order to identify any abnormalities related to the surgical procedure as well as urinary evaluation, related to the urine production and urine aspects.

Statistical analysis. Microsoft Office Excel software for Windows 7 was used to calculating average and paired t-test were used for the statistical analysis, considering significant differences at $\mathrm{p}<0.05$.

\section{RESULTS}

In the current study, cell adherence of lipoaspirate fractions to the plastic culture flasks was observed. Fibroblastoid cell morphology was also noted after third peal in culture (Fig.1). As for size and granularity, a homogeneous cell population was observed (Fig.2A).

As a second step, the frequency of these cell populations, derived from adipose tissue of rabbits, expressing MSC marker proteins were determined by flow cytometry. It is well known that MSCs express CD90, CD105 and CD73 while not express CD45. Using the negative control sample gates were traced in the SSC versus FL3 and FL1 versus FL2 dot-plots (Fig.2B,D). Thus, flow cytometry analyses revealed that $88.0 \%$ of cells express CD105 (Fig.2C,G), 73.7\% express CD90 (Fig.2E,G), 71.9\% express CD73 (Fig.2F,G),

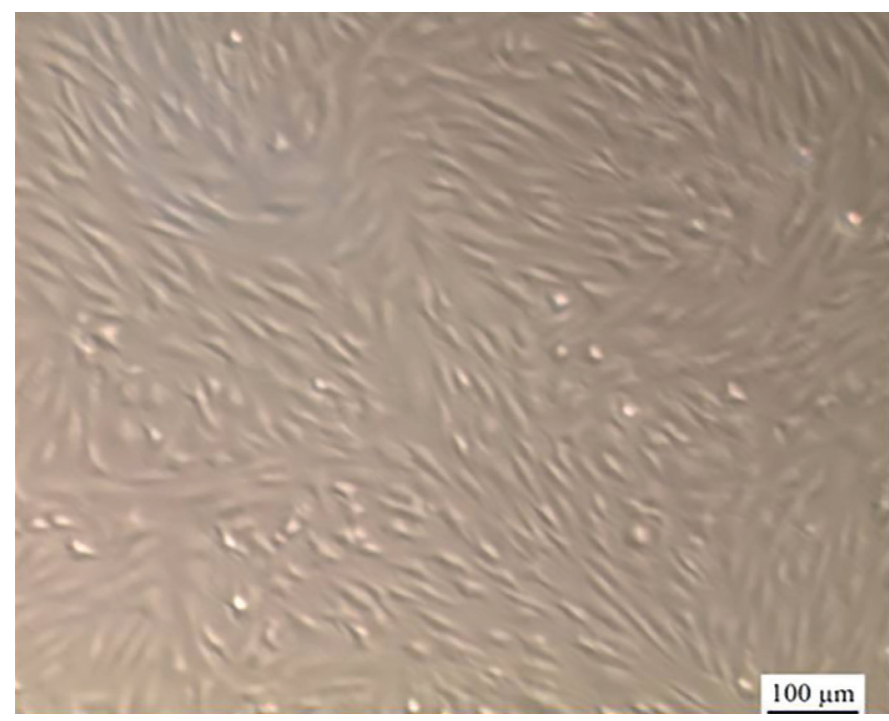

Fig.1. Morphological and cytometric characterization of mesenchymal stem cells (MSCs) derived from adipose tissue of rabbits. Fibroblastoid morphology observed after 10 days of culture. Bar $=100 \mu \mathrm{m}$.

and $87.6 \%$ do not express CD45 (Fig.2E,G). Moreover, flow cytometry analyses revealed that when cells were triply labeled with CD105, CD45 and CD90 antibodies, $62.7 \%$ of cells were simultaneously CD $105^{+} \mathrm{CD} 45^{-} \mathrm{CD} 90^{+}$, i.e., $62.7 \%$ of cells express MSC marker proteins and do not express hematopoietic marker protein (Fig.2C,E). As expected, when cells were triply labeled with CD105, CD73 and CD90 antibodies, $60.5 \%$ of cells were CD $105^{+} \mathrm{CD} 73^{+} \mathrm{CD} 90^{+}$ (Fig.2C,F). These results demonstrate that majority cells in culture derived from adipose tissue of rabbits simultaneously express MSC marker proteins.

Both treatments, CGcy and CGst, reached satisfactory clinical results and prevented allograft rejection. All animals had satisfactory recovery, with no clinical or behavioral change as a result of treatment throughout the postoperative evaluation period. Animals were monitored daily and at no time showed alterations were noted regarding food and water intake. Signs of peritonitis, caused by suture dehiscence of bladder or rejection of the implant, did not occur in any animal until 30 days of observation. A single dose of ADSCs applied in CGst demonstrated immunosuppressive effect, avoiding clinical graft rejection during the evaluation period and did not cause any adverse effect as a result of transplantation.

The majority of laboratorial tests performed in this experiment did not reveal significant differences between times before and after surgery (Fig.3). Serum biochemical (renal and hepatic) parameters were at physiological reference standards for rabbits during the evaluation time. Clinical reference ranges for rabbits were published by Melillo (2007) and are shown as dotted line. The ALT, AST, and BUN in the blood did not change in CGst compared to CGcy considering clinical preoperative (PO) and postoperative (30D; 30 days). There was significant difference in ALP level between CGcy and CGst, however, they remained within the physiological limits (Melillo 2007). 


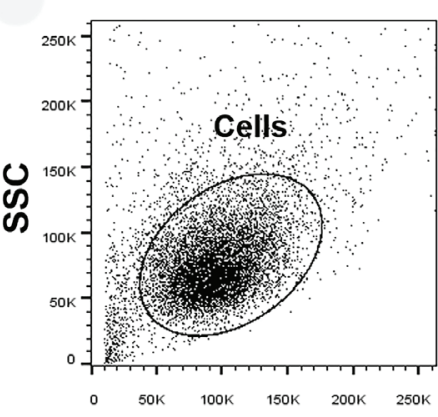

A $\quad$ FSC

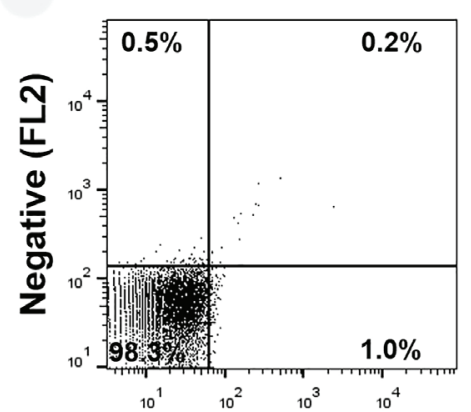

D Negative (FL1)

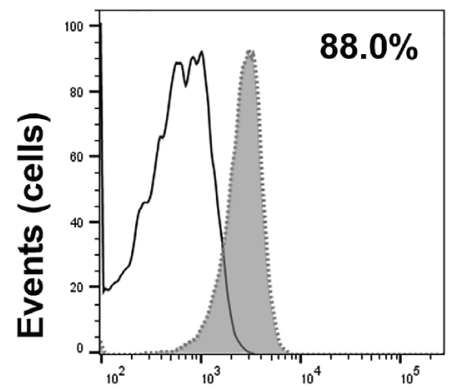

G CD105 PerCP-Cy5.5

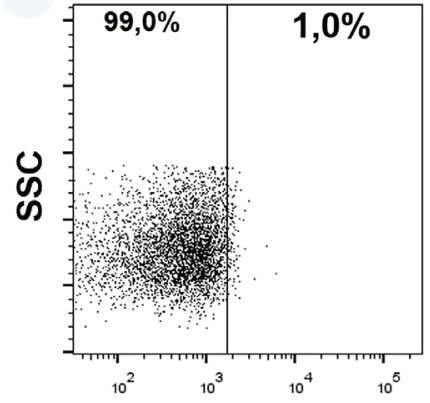

B Negative (FL3)

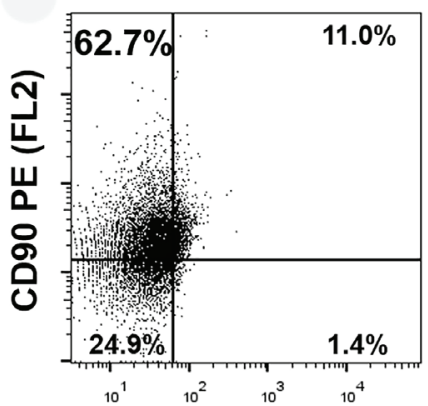

E CD45 FITC (FL1)

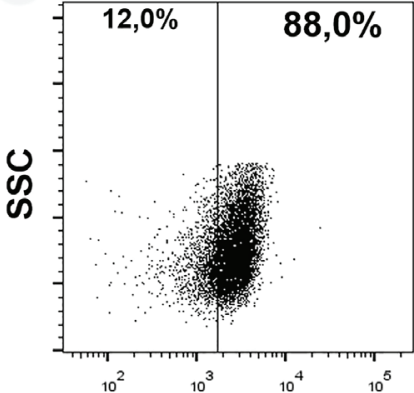

C CD105 PerCP-Cy5.5 (FL3)

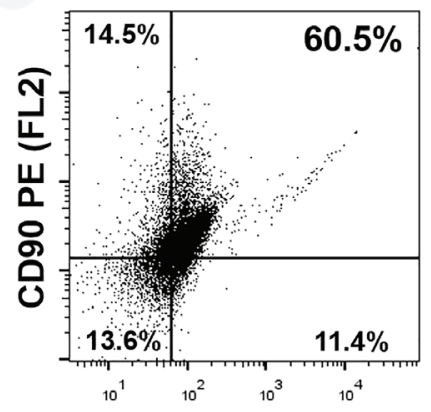

F CD73 FITC (FL1)

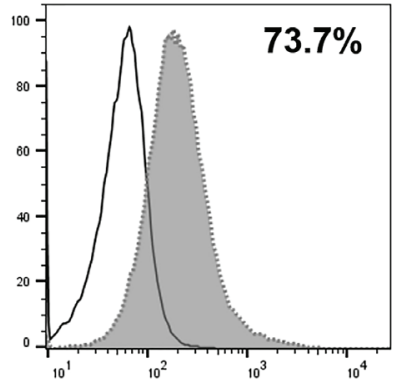

CD90 PE

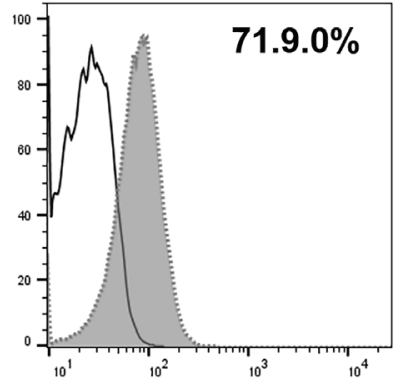

CD73 FITC

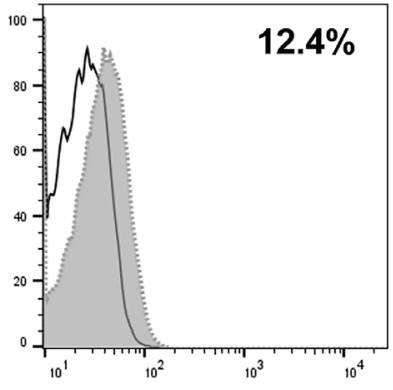

CD45 FITC

Fig.2. Phenotypic characterization of mesenchymal stem cells (MSCs) derived from adipose tissue of rabbits. (A) Gate selection by size (FSC, forward scatter) and granularity (SSC, side scatter) of the cells. Note the sample homogeneity with respect to these characteristics. (B) Using the negative control sample a gate was traced in the SSC versus FL3 dot-plot. Events observed in the right field were considered positive. The negative control sample consisted of cells not exposed to antibody labelling. (C) Flow cytometry dot-plot showing the percentage of cells expressing CD105 in culture derived from adipose tissue of rabbits. Anti-CD105 antibody was conjugated with PerCP-Cy5.5. (D) FL1 versus FL2 dot-plot showing the gate of the negative control sample in dot-plot, used for tracing the quadrants. Events observed beyond the lower left quadrant (containing the negative sample) were considered positive. (E) Dot-plot showing percentage of CD90+ (PE fluorophore) and CD45- (FITC fluorophore) cells derived from adipose tissue of rabbits after third passage in culture. (F) Dot-plot showing percentage of CD90+ (PE fluorophore) and CD73+ (FITC fluorophore) cells derived from adipose tissue of rabbits after third passage in culture. (G) Histograms showing individual data of frequency of CD105, CD90, CD73 and CD45 of mesenchymal stem cells (MSCs) derived from adipose tissue of rabbits.

Ultrasonography evaluation of urinary bladder after surgery of most animals (CGcy and CGst) showed similarity to the pre-operative state, considering integrity, thickness of the wall and content. Bladders in the pre- and post-operative examination revealed heterogeneous content, moderate cellularity, regular wall throughout its length, with no evidence of leakage of urine, a consistent finding of normal rabbit urinary bladder.

\section{DISCUSSION}

According to the International Society for Cellular Therapy, there are three minimum requirements for a population of cells to be classified as MSCs. The first is that MSCs are isolated from a population of mononuclear cells based on their selective to the plastic surface, when in culture. The second is that in more than $95 \%$ of the cultured cells, expression of CD105, 


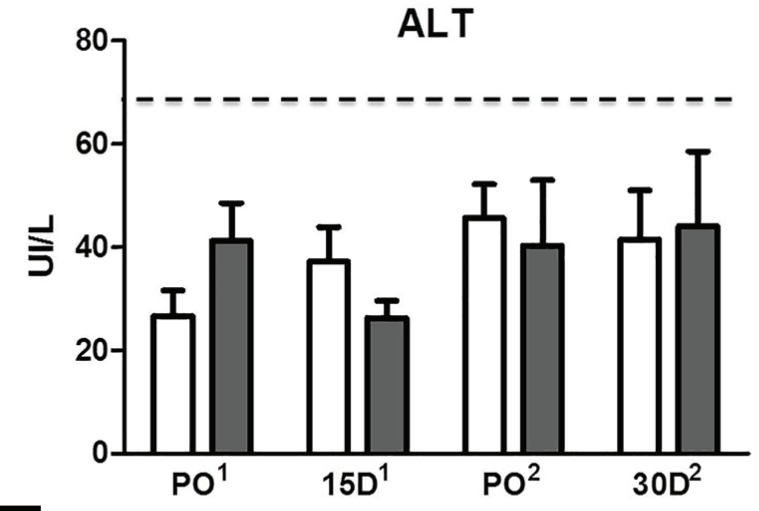

A

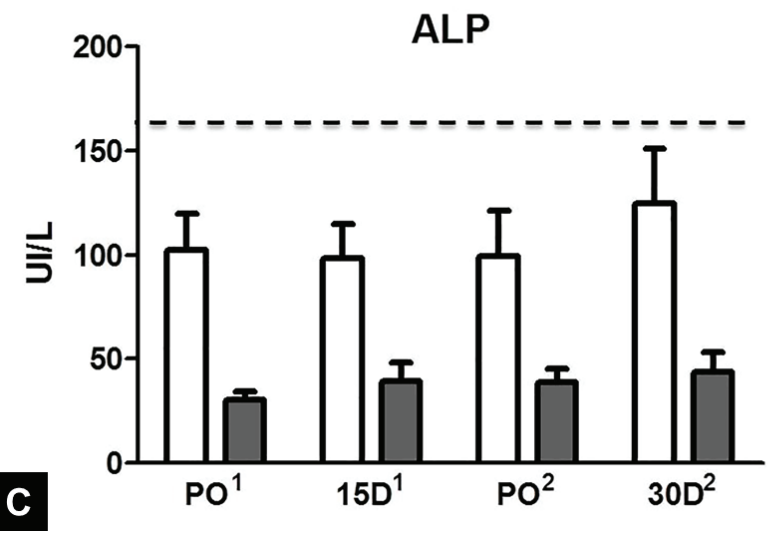

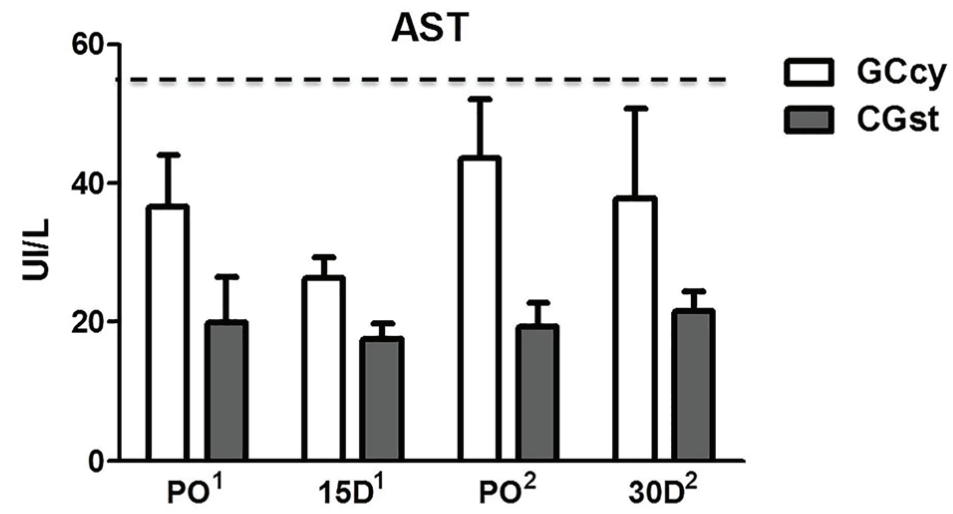

B

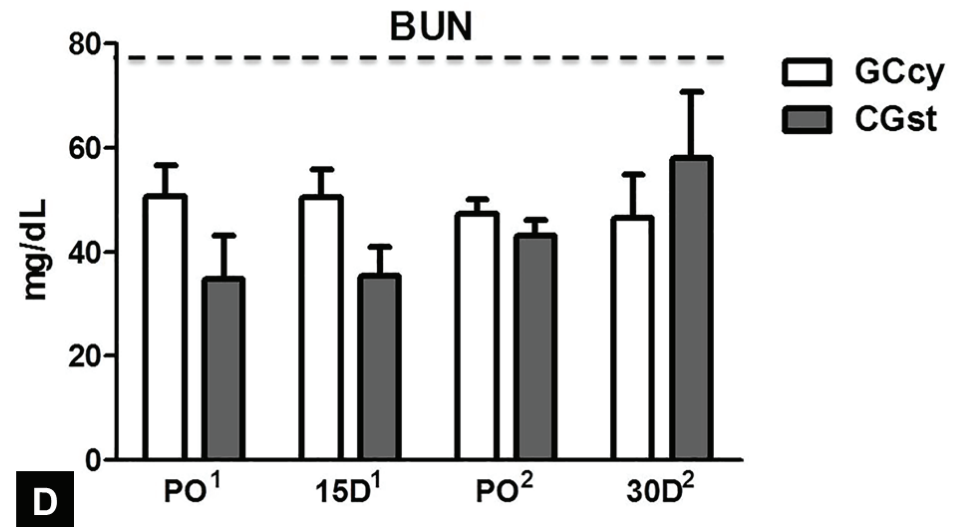

Fig.3. Clinical preoperative (PO) and postoperative (30D, 30 days) parameters of (A) ALT, alanine aminotransferase; (B) AST, aspartate aminotransferase; (C) ALP, alkaline phosphatase; (D) BUN, urea nitrogen in New Zealand White rabbits subjected to urinary bladder partial allograft. CGcy = Control Group treated with cyclosporine $\left(5 \mathrm{mg} / \mathrm{kg}^{-1}\right)$ i.v., every 24 hours; CGs = group received $0.8 \mathrm{ml}$ ADSCs $\left(1,6 \times 10^{5}\right.$ cells). The cells were applied once into the urinary wall, laterally to the suture between the graft and urinary bladder. Clinical reference ranges for rabbits were published by Melillo (2007). Limits are shown as dotted lines. The data are representative for two independent experiments conducted as biological triplicates and shown as mean \pm standard deviations $\left({ }^{*} \mathrm{P}<0.05\right.$ versus CGcy, ${ }^{* *} \mathrm{p}<0.01$ versus CGcy). ${ }^{1}$ Subgroup $15 d,{ }^{2}$ Subgroup $30 d$ (euthanasia).

CD73 and CD90 can be detected, while CD34, CD45, CD14 or CD11b, CD79, or CD19 and HLA-DR are not expressed. Finally, the cells need to be able to differentiate into bone, fat and cartilage (Bydlowski et al. 2009). In the current study, cell adherence to plastic culture flasks as well as fibroblastoid cell morphology identified cells used for allografts as MSCs (Torres et al. 2007, Bydlowski et al. 2009, Monteiro et al. 2010, Carvalho et al. 2013, Xu et al. 2015). Although have been identified eight surface markers for identifying MSCs, the International Society for Cellular Therapy agrees that the identification of markers CD105, CD73 and CD90, the absence of hematopoietic markers (CD45, for example), is sufficient for MSC immunophenotyping (Monteiro et al. 2010), as performed in our study. Similar with Dominici and co-workers (Dominici et al. 2006), the frequencies of MSC-specific CD105, CD73 and CD90 expressions and the absence of the hematopoietic marker CD45, revealed by our study, were more than $75 \%$ of the cultured cells. Possibly our data are a little lower than Dominici and co-workers due to differences in specificity of the antibodies, but they are sufficient to suggest the presence of MSCs.
No signs of peritonitis were observed caused by dehiscence of urinary bladder suture or rejection of the implant in any animal. Cyclosporine, used in the CGcy, is preferred by some researchers as an immunosuppressive agent in transplanted animals (Teixeira et al. 2007, Chaves et al. 2008). Pinto Filho et al. (2015) used cyclosporine to prevent rejection for 30 days after partial cystectomy surgery in rabbits and found no signs of implant rejection in all treated animals. Chaves et al. (2008) verified that cyclosporine prolonged survival of skin grafts in rabbits. Brandt et al. (2004) used azathioprine for 15 days in dogs as immunosuppressive agent in a study of bladder allograft and verified no signs of implant rejection during 18 months of evaluation. In our studies, ADSCs, applied in a single dose, demonstrated their immunosuppressive features, avoiding graft rejection during the period of clinical evaluation. It is unchallengeable that the immunomodulatory and/or immunosuppressive effect of ADSCs was consistently observed in several studies (Mizuno 2009, Casteilla et al. 2011, Lin et al. 2012, Gutiérrez-Fernández et al. 2013). According to Lin et al. (2012) ADSC's immunosuppressive activity appears to be mediated through an interleukin- 6 (IL-6)-dependent inhibition of dendritic cell differentiation 
and downregulation of MHC-II, CD40, and CD86 on mature dendritic cells. The same authors demonstrated in vitro that ADSCs do not cause alloreactivity, as they do not express MHC-II on their surfaces. However, they suppress the activity of $\mathrm{T}$ and B lymphocytes, an important feature for the treatment of organ allograft rejection and autoimmune disorders. In the present study, clinical observations and laboratory tests revealed that animals treated with allogeneic ADSCs did not show signs of rejection of grafts until 30 days of observation. According to Caplan (2007) immunomodulatory effects prevent recognition and expansion of T cells by blocking TNF- $\alpha$ and INF- $\gamma$-mediated effects, causing an increase in IL-10 levels. Although all of these immunomodulatory effects have not been well described, the available data clearly indicate that allogeneic MSCs can be used as therapeutic agents.

Postoperative clinical evaluation was realized in order to verify presence or absence of alterations after surgery. Haematuria happened 24 hours after surgery, but no on the subsequent days. As a verified by previous studies (Pinto Filho et al. 2015, 2016), it is a common finding during early postoperative of urinary bladder surgery. WBC showed no significant differences between pre- and postoperative period and between groups; during this time, leukocyte counting was in the normal range for the specie. Until 72 hours after surgery high urinary frequency was observed in some animals, sign that disappeared thereafter. Pollakiuria is a clinical sign found in inflammatory bladder diseases, due to overactivity of detrusor muscle (Teixeira et al. 2007). In this study no clinical signs of urinary tract infection in any animal happened, although some rabbits of CGcy group present bacteriuria.

Blood urea levels are indicative for renal function and can serve as an indication of glomerular filtration rate, though theoretically creatinine is more appropriate, because the quantity of creatinine present in the kidney is more constant and it is not reabsorbed by the renal tubules, such as urea. In addition, creatinine rates do not suffer variations according to the animal's diet and gastrointestinal bleeding among other parameters (Emanuelli et al. 2008). Creatinine values were maintained between $1.2-1.7 \mathrm{mg} \mathrm{dL}^{-1}$, within the normal range for this species $\left(0.5-2.5 \mathrm{mg} \mathrm{dL}^{-1}\right)$. Alkaline phosphatase (ALP) also showed significant differences between CGcy and CGst, in agreement with previous results (Emanuelli et al. 2008). However, CGcy following 30 days of surgery presented ALP activity levels above physiological limits. In agreement with previous studies (Özkan et al. 2012), serum ALP activity originates from bone and liver and varies with age; young individuals present ALP serum levels higher due to the rapid bone growth. This alteration could not be associated to age, because the animals in this study were adults; therefore, it could be attributed to cyclosporine use. According to Rezzani, cyclosporin stimulates the production of TGF- $\beta$ in the body, which is responsible for hepatic and renal injury, stimulation of neoplastic cells, heart disease and immunosuppression (Rezzani 2006). However, according to another author, in a study using dogs, the use of cyclosporine did not determine changes in serum ALP (Morini 2005).

The bladders showed at pre- and post-operative ultrasound scans to be filled by heterogeneous content with moderate cellularity and regular wall throughout its length, with no evidence of leakage of urine, showing a consistent finding of normal rabbit bladder. In the study of Teixeira et al. (2007), the first 30 days, the wall of the urinary bladder ultrasound image showed thickening and greater echogenicity, without, however, losing the integrity, similar to results found in some animals in the current study. Abilio et al. (2004) stated in his research with dogs that ultrasound images between seven and 21 days of both groups postoperatively showed minor changes in the conformation of the urinary bladders located on the face of grafting, which however, disappeared after 28 days.

\section{CONCLUSIONS}

Based on clinical data and anatomical analysis, ADSCs prevent allograft rejection of the urinary bladder, as confirmed by clinical data and anatomic analysis.

Adipose-derived cells used for engraftment in this study were characterized by fibroblast morphology, the MSC-specific CD105, CD73 and CD90 expression and by the absence of the hematopoietic marker CD45.

Therapeutic applications can be foreseen from our pre-clinical study.

Acknowledgements.- The Coordenação de Pessoal de Nível Superior (CAPES) is acknowledged for a doctoral scholarship awarded S.T.L.P.F. H.U. acknowledges grant support from Fundação de Amparo à Pesquisa do Estado de São Paulo (Fapesp Project No. 2012/50880-4) and Conselho Nacional de Desenvolvimento Científico e Tecnológico (CNPq Project No. 486294/2012-9 and 467465/2014-2), Brazil. MMP is grateful for a post-doctorate fellowship granted by Fapesp (Project No. 2015/19478-3).

Conflict of interest statement.- Authors declare to have no conflicts of interest.

\section{REFERENCES}

Abílio E.J., Ferreira M.L.G., Carvalho E.C.Q., Chaudon M.B.O., Dória P.B.A., Nunes V.A. \& Branco T.R.C. 2004. Ileocistoplastia em cães (Canis familiaris): descrição da técnica cirúrgica. Braz. J. Vet. Res. Anim. Sci. 41:197-198.

Barretto L.S.S., Lessio C., Nakamura A.N.S., Lo Turco E.G., Silva C.G., Zambon J.P., Gozzo F.C., Pilau E.J. \& Almeida F.G. 2014. Cell kinetics, DNA integrity, differentiation, and lipid fingerprinting analysis of rabbit adipose-derived stem cells. In Vitro Cell. Develop. Biol., Anim. 50(9):831-839. <http://dx.doi. org/10.1007/s11626-014-9782-x> <PMid:24934234>

Brandt F.T., Lorenzato F.R. \& Albuquerque C.D.C. 2004. Transplante de bexiga: estudo piloto. Acta Cir. Bras. 19(4):448-455. <http://dx.doi.org/10.1590/ S0102-86502004000400015>

Bydlowski S.P., Debes A.A., Maselli L.M.F. \& Janz F.L. 2009. Características biológicas das células-tronco mesenquimais. Revta Bras. Hematol. Hemoter. 31(1):25-35. <http://dx.doi.org/10.1590/S1516-84842009005000038>

Caplan A.I. 2007. Adult mesenchymal stem cells for tissue engineering versus regenerative medicine. J. Cell Physiol. 213(2):341-347. <http://dx.doi. org/10.1002/jcp.21200><PMid:17620285>

Carvalho A.M., Yamada A.L.M., Golim M.A., Álvarez L.E.C., Jorge L.L., Conceição M.L., Deffune E., Hussni C.A. \& Alves A.L.G. 2013. Characterization of mesenchymal stem cells derived from equine adipose tissue. Arq. Bras. Med. Vet. Zootec. 65(4):939-945. <http://dx.doi.org/10.1590/S0102$09352013000400001>$

Casteilla L., Planat-Benard V., Laharrague P. \& Cousin B. 2011. Adiposederived stromal cells: their identity and uses in clinical trials, an update. World J. Stem Cells 3(4):25-33. <http://dx.doi.org/10.4252/wjsc.v3.i4.25> <PMid:21607134>

Chaves D.N.B., Alberti L.R. \& Petroianu A. 2008. Estudo comparativo dos efeitos da talidomida, da ciclosporina e do diclofenaco na sobrevida de aloenxertos cutâneos em coelho. Revta Assoc. Med. Bras. 54(1):42-47. <http://dx.doi.org/10.1590/S0104-42302008000100019> 
Dominici M., Le Blanc K., Mueller I., Slaper-Cortenbach I., Marini F., Krause D., Deans R., Keating A., Prockop D.J. \& Horwitz E. 2006. Minimal criteria for defining multipotent mesenchymal stromal cells, the International Society for Cellular Therapy position statement. Cytotherapy 8(4):315-317. <http://dx.doi.org/10.1080/14653240600855905> <PMid:16923606>

Emanuelli M.P., Lopes S.T.A., Maciel R.M., Garmatz B.C. \& Tavares M.O. 2008. Concentração sérica de fosfatase alcalina, gama-glutamil transferase, ureia e creatinina em coelhos (Oryctolagus cuniculus). Ciênc. Anim. Bras. 9(1):251-255.

Gutiérrez-Fernández M., Rodríguez-Frutos B., Ramos-Cejudo J., Teresa Vallejo-Cremades M., Fuentes B., Cerdán S. \& Díez-Tejedor E. 2013. Effects of intravenous administration of allogenic bone marrow- and adipose tissuederived mesenchymal stem cells on functional recovery and brain repair markers in experimental ischemic stroke. Stem Cell Res. Ther. 4(1):1-12. <http://dx.doi.org/10.1186/scrt159><PMid:23356495>

Larocca R.A., Moraes-Vieira P.M., Bassi Ê.J., Semedo P., Almeida D.C., Silva M.B., Thornley T., Pacheco-Silva A. \& Câmara N.O.S. 2013. Adipose tissue-derived mesenchymal stem cells increase skin allograft survival and inhibit Th-17 immune response. Plos One 8(10):e76396. <http://dx.doi.org/10.1371/ journal.pone.0076396><PMid:24124557>

Leite M.T.C., Freitas-Filho L.G., Oliveira A.S., Semedo-Kuriki P., Laks M., Arias V.E.A. \& Peixoto P.S. 2014. The use of mesenchymal stem cells in bladder augmentation. Pediatr. Surg. Int. 30(4):361-370. <http://dx.doi. org/10.1007/s00383-014-3465-2><PMid:24500280>

Lin C.S., Lin G. \& Lue T.F. 2012. Allogeneic and xenogeneic transplantation of adipose-derived stem cells in immunocompetent recipients without immunosuppressants. Stem Cells Develop. 21(15):2770-2778. <http:// dx.doi.org/10.1089/scd.2012.0176><PMid:22621212>

Melillo A. 2007. Rabbit clinical pathology. J. Exot. Pet Med. 16(3):135-145. <http://dx.doi.org/10.1053/j.jepm.2007.06.002>

Mizuno H. 2009. Adipose-derived stem cells for tissue repair and regeneration: ten years of research and a literature review. J. Nippon Med. School 76(2):56-66. <http://dx.doi.org/10.1272/jnms.76.56><PMid:19443990>

Monteiro B.S., Argolo Neto N.M. \& Del Carlo R.J. 2010. Células-tronco mesenquimais. Ciência Rural 40(1):238-245. <http://dx.doi.org/10.1590/ S0103-84782010000100040>

Morini A.C. 2005. Efeitos da ciclosporina A sobre a função renal e hepática de cães da raça Golden Retriever normais ou afetados pela distrofia muscular. Dissertação de Mestrado, Universidade de São Paulo, São Paulo. 106p. <http://dx.doi.org/10.11606/D.10.2005.tde-29062006-175751>.

Nery A.A., Nascimento I.C., Glaser T., Bassaneze V., Krieger J.E. \& Ulrich H. 2013. Human mesenchymal stem cells: from immunophenotyping by flow cytometry to clinical applications. Cytometry A 83A(1):48-61. <http:// dx.doi.org/10.1002/cyto.a.22205> <PMid:23027703>

Özkan C., Kaya A. \& Akgül Y. 2012. Normal values of haematological and some biochemical parameters in serum and urine of New Zealand White rabbits. World Rabbit Sci. 20(4):253-259. <http://dx.doi.org/10.4995/ wrs.2012.1229>
Pillat M.M., Correa B.L., Da Rocha C.F., Muller G.C., Lopes R.P., Lampert S.S. Teixeira A.L., Menna-Barreto M. \& Bauer M.E. 2009. Changes in T cell phenotype and activated MAPKs are correlated to impaired cellular responses to antigens and glucocorticoids during HTLV-I infection. J. Neuroimmunol. 216(1/2):76-84. <http://dx.doi.org/10.1016/j.jneuroim.2009.08.016> $<$ PMid:19766325>

Pinto Filho S.T.L., Oliveira M.T., Aramburú Junior J.S., Glanzner W.G., Silva T.O., Feranti J.P.S., Gonçalves P.B.D., Cruz I.B.M., Brun M.V. \& Pippi N.L. 2015. Avaliações clínica, ecográfica e anatomofisiológica do alotransplante parcial de vesícula urinária com células-tronco mesenquimais alogênicas derivadas do tecido adiposo em coelhos. Arq. Bras. Med. Vet. Zootec. 67(5):13041312. <http://dx.doi.org/10.1590/1678-4162-8148>

Pinto Filho S.T.L., Dalmolin F., Medina Pinho R., Feltrin Giglio C., Visentini Felin D., Lopes de Faria K., Da Rosa Vargas A., Veloso Brun M., Braz Vaz M.A. \& Pippi N.L. 2016. Characterization of bladder calculi and urinalysis in rabbits (Oryctolagus cuniculus) treated with mesenchymal adipose-derived stem cells (ADSCs) after partial urinary bladder allotransplantation. Semina, Ciênc. Agrárias 37(2):867-876.

Rezzani R. 2006. Exploring cyclosporine A-side effects and the protective role-played by antioxidants: the morphological and immunohistochemical studies. Histol. Histopathol. 21(3):301-316. <PMid:16372251>

Sousa B.R., Parreira R.C., Fonseca E.A., Amaya M.J., Tonelli F.M., Lacerda S.M., Lalwani P., Santos A.K., Gomes K.N., Ulrich H., Kihara A.H. \& Resende R.R. 2014. Human adult stem cells from diverse origins: an overview from multiparametric immunophenotyping to clinical applications. Cytometry A 85(1):43-77. <http://dx.doi.org/10.1002/cyto.a.22402><PMid:24700575>

Tárnok A., Ulrich H. \& Bocsi J. 2010. Phenotypes of stem cells from diverse origin. Cytometry A 77A(1):6-10. <http://dx.doi.org/10.1002/cyto.a.20844> <PMid:20024907>

Technau A., Froelich K., Hagen R. \& Kleinsasser N. 2011. Adipose tissue-derived stem cells show both immunogenic and immunosuppressive properties after chondrogenic differentiation. Cytotherapy 13(3):310-317. <http:// dx.doi.org/10.3109/14653249.2010.504769><PMid:20795757>

Teixeira M.W., Rezende C.M.F., Silva Júnior V.A., Teixeira M.J.D., Silva E.C. \& Barbosa D.G. 2007. Avaliação clínica e histopatológica de alo-transplante de bexiga em cães. Arq. Bras. Med. Vet. Zootec. 59(2):350-357. <http:// dx.doi.org/10.1590/S0102-09352007000200013>

Torres F.C., Rodrigues C.J., Stocchero I.N. \& Ferreira M.C. 2007. Stem cells from the fat tissue of Rabbits: an easy-to-find experimental source. Aesth. Plastic Surg. 31(5):574-578. <http://dx.doi.org/10.1007/s00266-0070001-y><PMid:17576503>

Xu N., Guo S., Wang Y., Sun Q. \& Wang C. 2015. Transplantation of adipose tissue-derived stromal cells promotes the survival of venous-congested skin flaps in rabbit ear. Cell Biochem. Biophys. 71(2):557-563. <http:// dx.doi.org/10.1007/s12013-014-0234-8><PMid:25190589>

Zuk P.A., Zhu M., Ashjian P., De Ugarte D.A., Huang J.I., Mizuno H., Alfonso Z.C., Fraser J.K., Benhaim P. \& Hedrick M.H. 2002. Human adipose tissue is a source of multipotent stem cells. Mol. Biol. Cell. 13(12):4279-4295. <http://dx.doi.org/10.1091/mbc.e02-02-0105> <PMid:12475952> 